Ove Christensen

\section{Lille spejl på væggen der}

Anders Toftgaard og Ian Halvdan Hawkesworth (red.): Nationale spejlinger. Kbh. 2003 (Museum Tusculanum).

I den store interesse for dansk film, man har oplevet de seneste mange år, har det især været de spændende og udfordrende film, der har stået i centrum. Opmærksomheden har endvidere været rettet mod filmæstetiske emner eller enkeltpersoner i dansk film. Men film er meget andet og mere end filmæstetik og filmpersonligheder, hvilket en ny filmbog, Nationale spejlinger, viser. Bogens to redaktører Anders Toftgaard og Ian Halvdan Hawkesworth peger i forordet på, at den store danske samtidsroman ikke skal søges i litteraturen, men i de visuelle medier tv og film. Hvis man gerne vil kende til et lands "nationale bevidsthed', så er de trivielle tv-genrer et af de bedste steder at søge, da disse fremstiller det typiske. Her taler man til det, seeren i forvejen ved og mener. Derfor kan man også få et indblik i, hvordan den gennemsnitlige nationalborger forstår sig selv, og hvad denne type netop ikke interesserer sig for eller ikke tematiserer - 'det andet'.

Pointen med Nationale spejlinger er, at de danske film også præsenterer den danske dagligdag, så man kan se kultur 'in performance', hvilket vil give "en idé om, hvad der optager danskerne $o g$ hvilke forandringer, der er sket i det danske samfund inden for de seneste år...« (p. 8) De danske film ses som spejlinger af det kulturelle fællesskab, og bogens sigte er at få disse spejlbilleder frem i lyset, for at vi kan blive klogere på os selv. Det handler altså om at se de danske film som en tematisering af danskhed og national identitet. $\mathrm{Og}$ det er oplagt, at mange film kredser om hverdagslivet. Her er karaktererne ikke 'bigger than life', men netop 'almindelige mennesker’ - eller forsøg på spejlinger af sådanne.

Projektet er interessant, men desværre har de forskellige bidragsydere ikke været interesserede medspillere. Antologiens klare tematik flyder temmelig meget ud i bogens artikler, der næsten alle hver for sig er både gode og interessante. Det nationale spejl er der imidlertid ikke mange af dem, der forholder sig noget videre til. Lars Brink skriver indsigtsfuldt om udviklingen af det danske sprog i film, men artiklen bliver aldrig til en præsentation af, hvordan sproget spejler kulturelle glidninger ud over det helt generelle om et mere ungdommeligt og hverdagspræget sprog. Michael Eigtved skriver meget overordnet om danske komedier, men netop ikke om national humor og humortradition $\mathrm{i}$ en kulturhistorisk optik. Mehmet Ümit Necef, som skriver om billedet af 'de fremmede' i nutidige danske film, retter ganske vist blikket mod, hvad der konstituerer 'det onde' i dagens Danmark, men det bliver mest til et opgør med halalhippier og en påpegning af den pædofile som 'det onde'.

Mette Hjort har skrevet en interessant artikel om 'kulturarvsfilm' i Danmark. Det undrer Hjort, at den brede engelske interesse for at tale om 'heritage film' som en selvstændig genre ikke har slået an i Danmark. Denne genre er kendetegnet ved at være filma- 
tiseringer af den nationale fortid, men netop æstetisk fremstillet som for evigt tabt. Der filmes på afstand med mange totaler af 'nationale landskaber' og store godser eller pittoreske scenerier. Filmene er nationalromantiske i deres fremvisen af fordums storhed og renhed. Men der findes faktisk ikke nogen udpræget tradition i Danmark for denne type af fremstillinger. Fortiden dramatiseres i højere grad. Det lykkes Hjort at finde et par gode eksempler som Babettes gastebud (Axel) og Barbara (Malmros), men ellers bruger hun de danske eksempler på at vise, at kulturarvsgenren skal udvikles og nuanceres for at blive brugbar. Dermed er det vel heller ikke så underligt, at genren ikke har nogen central placering i en dansk sammenhæng?

Mette Hjorts artikel er den, der mest direkte går i dialog med bogens overordnede tema. Men også i bogens sidste sektion diskuteres det nationale. Redaktørerne har haft den gode ide at lade 'de fremmede' kaste et blik på dansk film. Trevor Elkinson skriver om, hvordan man i USA har haft en fornemmelse af dansk eller skandinavisk film ud fra Babettes gastebud og Pelle Erobreren, da de begge blev belønnede med Oscars for bedste udenlandske film i henholdsvis 1987 og 1988. Han betegner disse film som 'kostumefilm', hvilket ligger pænt i forlængelse af Hjorts kulturarvsfilm. Den placering de danske film her kunne indtage blev dog hurtigt fulgt op af engelsksprogede kostumefilm startende med Vorelse med udsigt, som er arketypisk for 'heritage film'. Men fra midt i 1990erne er der kommet en ny bevågenhed i USA for independent produktioner, hvilket også passer godt med $A$
Danish New Wave, hvori dogmefilmene og andre mere skæve film passer glimrende.

De udenlandske blikke på dansk film bekræfter betydningen af 'De to tårne', som er titlen på engelske Mark Le Fanus artikel. Der tænkes på Carl Th. Dreyer og Lars von Trier. Disse to instruktører bliver de ypperste repræsentanter for dansk film. Det sjove ved det er, at de ikke er særligt danske i deres film. Mange af dem handler ikke om danske forhold og er ikke med danske skuespillere. Vigtigst er dog, at deres æstetik ikke er speciel nationalt funderet.

Grodal har skrevet en sjov og surt diskuterende artikel om, at vores forhold til film i høj grad bestemmes af, hvor vidt vi er enige med en givet films værdier. Artiklen viser fint, hvilke type af fortællinger, der er fremme i dansk film. Men det nationale er underdrejet, hvilket også gælder for Peter Schepelerns gode introduktion til de danske dogmefilm. Han redegør her for, hvilke filmæstetiske og kunstneriske traditioner og ideer, dogmefilmene står i gæld til. Vi får også en lille gennemgang af nyere danske film af Pil Gundelach Brandstrup og Eva Novrup Redvall.

Altså alt i alt en række gode artikler, der dog ikke samles af antologiens overordnede tema. Det gør selvfølgelig mindre, når blot artiklerne er gode, men det forvirrer læsningen, når man tror, at man er ved at læse om nationale spejlinger og så får alt muligt andet. Emnet kunne således stadig trænge til den fordybelse, da forholdet mellem national identitet og nationale kulturelle udtryk langt fra er indlysende set i globaliseringens lys. 